${ }^{\circ}$ Entomologica Fennica. 3 November 1997

\title{
Arthropods on oak branches in SW Finland, collected by a new trap type
}

\author{
Seppo Koponen, Veikko Rinne \& Tom Clayhills
}

Koponen, S., Rinne, V. \& Clayhills, T. 1997: Arthropods on oak branches in SW Finland, collected by a new trap type. - Entomol. Fennica 8: 177-183.

Arthropods moving on large horizontal branches of old oaks (Quercus robur L.) in seven oak woodlands, SW Finland, were studied using a new trap type. The most abundant groups included Formicidae (Hym.), Oribatida (Acari), Thysanoptera, Nematocera (Dipt.), Collembola, Auchenorrhyncha (Hom.), Coleoptera, Araneae, Psocoptera and Hemiptera. The last three groups showed the least intersite variation in numbers of individuals. About 120 abundant, rare and other interesting species of Diplopoda (4 species mentioned), Chilopoda (2), Araneae (19), Opiliones (4), Pseudoscorpionida (1), Oribatida (9), Psocoptera (9), Blattodea (1), Neuroptera (1), Homoptera (10), Heteroptera (13), Coleoptera (25), Lepidoptera (14) and Formicidae (6) are listed, and the new trap is described.

Seppo Koponen \& Veikko Rinne, Zoological Museum, University of Turku, FIN-20014 Turku, Finland

Tom Clayhills, Tennbyntie 33-35 B 4, FIN-21600 Parainen, Finland

Received 30 April 1996, accepted 24 April 1997

\section{Introduction}

Oak (Quercus robur L.) reaches its northern limit in southernmost Finland. The oak woodlands are small in area, with the largest forests found in the archipelago and in the narrow coastal area of southwesternmost Finland. The largest oak forest in Finland, almost 90 hectares, is situated on the island of Ruissalo, in Turku.

The fauna of local oak forests in Finland has been dealt with by several authors, their materials originating especially from Ruissalo. Laamanen (1938) and Lahtiperä (1955) described the beetle fauna, Salmikivi (1931) and Koponen et al. (1990) studied oak-feeding lepidopterans. In addition, Karhu et al. (1995) listed the threatened species of the orders Heteroptera, Lepidoptera and Coleoptera found in Ruissalo.

In Europe, there are some studies on arthropod groups of trunks (e.g. Nicolai 1986) or hollow trees (Ruzicka \& Bohac 1991), but the total fauna living on branches of old oaks has not been studied.

In the present paper, data on fauna living or moving on large horizontal branches of old oak trees near the city of Turku is presented, and a new trap type is described. This work is part of an investigation of invertebrates in protected oak forests in southwestern Finland (Rinne et al. 1997). Two groups in the present material are discussed in more detail separately, i.e. spiders (Koponen 1996) and psocopterans (Kanervo \& Rinne 1996). 


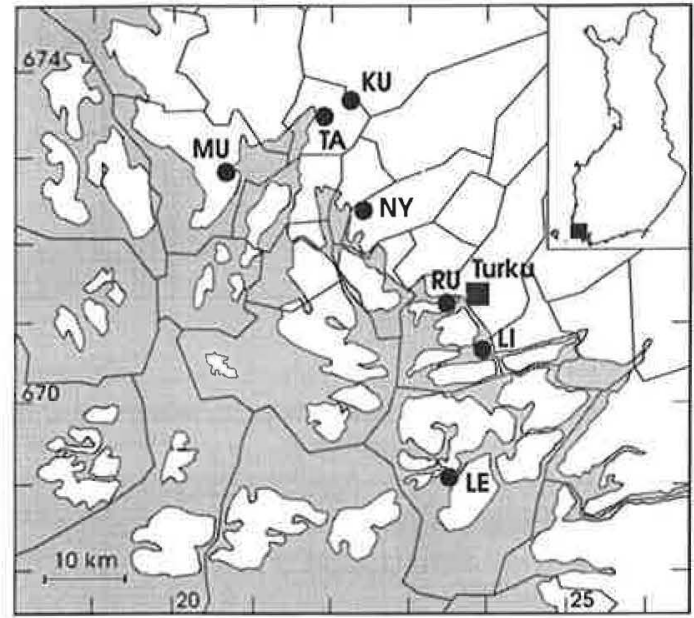

Fig. 1. Location of the oak forests studied in SW Finland. RU = Ruissalo, LE = Lenholm, NY = Nyynäinen, TA $=$ Tammimäki, $\mathrm{KU}=$ Kurasmäki, $\mathrm{LI}=$ Linnavuori, MU = Muntti. The municipalities and $10 \times$ $10 \mathrm{~km}$ squares of the Finnish uniform Grid $27^{\circ} \mathrm{E}$ system are shown.

\section{Material and methods}

\subsection{Study sites}

The isolated oak forests studied (Table 1) lie at $60^{\circ} 15^{\prime}-$ $60^{\circ} 40^{\prime} \mathrm{N}$, near the city of Turku (Fig. 1). They are all near the sea, less than $5 \mathrm{~km}$ from the coastline. All have been within the influence of human activity, for example grazing by cattle and timber cutting, for a long period. The forests are presently protected.

At most sites, other trees, usually deciduous ones, grow near the oaks with branch traps. In Ruissalo, these include Tilia, Acer, Sorbus, Prunus, Betula and Pinus; in Lenholm, Sorbus, Prunus, Betula, Pinus and Picea; in Nyynäinen, Tilia; in Tammimäki, Acer; in Linnavuori, Tilia, Sorbus, Betula and Picea and, in Muntti, Acer, Betula and Prunus.

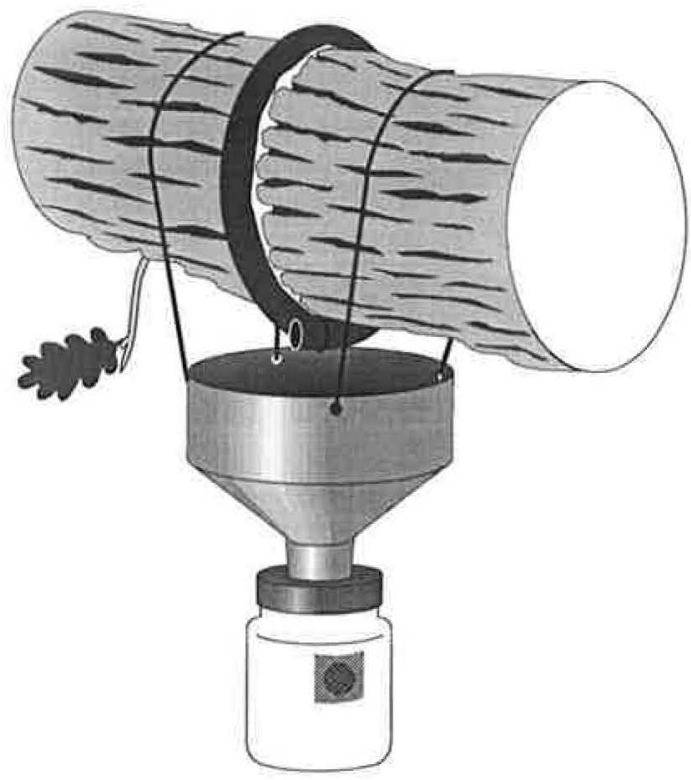

Fig. 2. The branch trap used. For details, see the text,

\subsection{Trap}

We constracted a new type of trap for collecting arthropods actively moving on large oak branches. This trap has no cover, i.e. no dark or sheltered hiding place which could either attract or repel branch dwellers. In this respect, it differs from branch traps used earlier (e.g. Simon 1995: fig. 7).

The trap consists of a collar around the branch, a plastic funnel, and a container (Fig. 2). The collar (water pipe, diameter $15 \mathrm{~mm}$ ) was fitted tightly around the branch with lute and cable tie. The collar was brushed with FLUON to give a teflon-like slippery surface. The funnel (upper diameter ca. $22 \mathrm{~cm}$ ) was situated beneath the collar, at a distance of about $5 \mathrm{~cm}$, fastened with plastic string. Placing the traps below thick branches and under/within the oak canopy diminished the effect of rainfall. In any case, the container $(0.51)$ had an overflow hole covered by gauze. Saturated $\mathrm{NaCl}$ solution was used as a preservation liquid.

Table 1. The seven oak woodlands studied.

\begin{tabular}{lccrcc}
\hline & $\begin{array}{c}\text { Grid } 27^{\circ} \mathrm{E} \\
\text { squares }\end{array}$ & $\begin{array}{c}\text { Area } \\
\text { (ha) }\end{array}$ & \multicolumn{1}{c}{$\begin{array}{c}\text { Trapping } \\
\text { period }\end{array}$} & $\begin{array}{c}\text { Average trap } \\
\text { height (cm) }\end{array}$ & $\begin{array}{c}\text { Average diam. of } \\
\text { oaks with traps }(\mathrm{cm})\end{array}$ \\
\hline Ruissalo (Turku) & $6712: 234-6$ & 87 & 6. V.-29.IX.1994 & 420 & 75 \\
Lenholm (Parainen) & $6690: 235$ & 8 & 9. V.-29.IX.1994 & 470 & 100 \\
Nyynäinen (Lemu) & $6724: 224-5$ & 3.3 & 13. V.-30.IX.1994 & 420 & 80 \\
Tammimäki (Mietoinen) & $6735: 219$ & 3.1 & 13. V.-30.IX.1994 & 480 & 115 \\
Kurasmäki (Mynämäki) & $6737: 222$ & 2.3 & 13. V.-30.IX.1994 & 480 & 80 \\
Linnavuori, Kulho (Turku) & $6706: 239$ & 1.1 & 2.VI.-2.X.1994 & 360 & 55 \\
Muntti (Taivassalo) & $6729: 206$ & 0.5 & 13.V.-30.IX.1994 & 470 & 100 \\
\hline
\end{tabular}


The branch traps were fitted on large (diameter 15$30 \mathrm{~cm}$; mean $20 \mathrm{~cm}$ ), more or less horizontal branches of old oaks. The branches were covered by lichens and often also by a moss layer. The traps were at a height of 3-6 m, on average $4.5 \mathrm{~m}$. There were five traps at all study sites except Linnavuori, where there were three. Traps were emptied within 4-5-week intervals. The material is deposited mainly in the Zoological Museum of the University of Turku.

\section{Results}

\subsection{Fauna on oak branches}

The arthropod material collected by branch traps consists of about 33000 specimens (Table 2). Oribatids were included, but other mite groups were omitted in the above figures. Only a part of the groups

Table 2. Arthropod material caught by branch traps on old oaks at seven study sites ( 5 traps/site, except Linnavuori, which had 3). RU = Ruissalo, LE = Lenholm, NY = Nyynäinen, TA = Tammimäki, $K U=$ Kurasmäki, $\mathrm{LI}=\mathrm{Linnavuori,} \mathrm{MU}=$ Muntti; ind/tr = individuals/trap/summer.

\begin{tabular}{|c|c|c|c|c|c|c|c|c|c|}
\hline & $\mathrm{RU}$ & LE & NY & TA & KU & LI & MU & Total & Ind/tr \\
\hline Diplopoda & 29 & 33 & 6 & 9 & 1 & 19 & 8 & 105 & 3.2 \\
\hline Chilopoda & 12 & 1 & 1 & - & - & - & 2 & 16 & 0.5 \\
\hline Tardigrada & - & - & 1 & 1 & 1 & - & 5 & 8 & 0.2 \\
\hline Pseudoscorpionida & 2 & - & - & 1 & - & 2 & - & 5 & 0.2 \\
\hline Opiliones & 6 & 10 & 5 & 8 & - & 22 & 2 & 53 & 1.6 \\
\hline Araneae & 176 & 163 & 120 & 161 & 133 & 128 & 162 & 1043 & 31.6 \\
\hline Acari: Oribatida ${ }^{\star}$ & 411 & 855 & 898 & 1452 & 600 & 63 & 481 & 4760 & 144.2 \\
\hline Collembola & 763 & 299 & 371 & 427 & 810 & 122 & 323 & 3115 & 94.4 \\
\hline Psocoptera & 253 & 215 & 99 & 85 & 83 & 74 & 129 & 938 & 28.4 \\
\hline Blattodea & 46 & 3 & 11 & 13 & 44 & 32 & 5 & 154 & 4.7 \\
\hline Dermaptera & - & - & - & - & - & 1 & - & 1 & 0.0 \\
\hline Ephemeroptera & - & - & - & - & 1 & - & 1 & 2 & 0.1 \\
\hline Plecoptera & - & - & - & - & 2 & - & - & 2 & 0.1 \\
\hline Neuroptera adults & 6 & 3 & 2 & 2 & 6 & 3 & 1 & 23 & 0.7 \\
\hline larvae & 15 & 10 & 6 & 5 & 21 & 11 & 4 & 72 & 2.2 \\
\hline Trichoptera & 5 & 24 & 6 & 42 & 73 & 5 & 11 & 166 & 5.0 \\
\hline Thysanoptera & 520 & 1050 & 364 & 150 & 392 & 56 & 874 & 3406 & 103.2 \\
\hline \multicolumn{10}{|l|}{ Homoptera } \\
\hline Psyllodea & - & - & - & 1 & - & - & 11 & 12 & 0.4 \\
\hline Aphidoidea & 112 & 16 & 65 & 32 & 47 & 27 & 79 & 378 & 11.5 \\
\hline Auchenorrhyncha & 30 & 8 & 2938 & 7 & 6 & 33 & 5 & 3027 & 91.7 \\
\hline Heteroptera & 185 & 102 & 192 & 173 & 91 & 79 & 83 & 905 & 27.4 \\
\hline Coleoptera adults & 439 & 147 & 138 & 165 & 127 & 96 & 128 & 1240 & 37.6 \\
\hline larvae & 5 & 4 & 13 & 3 & 7 & 1 & 6 & 39 & 1.2 \\
\hline Lepidoptera adults & 323 & 34 & 68 & 83 & 87 & 30 & 37 & 662 & 20.1 \\
\hline larvae & 194 & 58 & 107 & 61 & 146 & 37 & 61 & 664 & 20.1 \\
\hline \multicolumn{10}{|l|}{ Hymenoptera } \\
\hline Formicidae & 6280 & 5 & 24 & 104 & 54 & 860 & 7 & 7334 & 222.2 \\
\hline Other adults & 153 & 66 & 85 & 83 & 174 & 55 & 68 & 684 & 20.7 \\
\hline Symphyta larvae & - & 36 & - & 8 & 2 & 4 & - & 50 & 1.5 \\
\hline \multicolumn{10}{|l|}{ Diptera } \\
\hline Nematocera & 468 & 660 & 475 & 480 & 561 & 138 & 542 & 3324 & 100.7 \\
\hline Brachycera-Cyclorrhapha & a 237 & 28 & 42 & 79 & 90 & 26 & 39 & 541 & 16.4 \\
\hline larvae & 69 & 39 & 8 & 10 & 35 & 28 & 20 & 209 & 6.3 \\
\hline "Groups" & 25 & 25 & 25 & 27 & 26 & 26 & 27 & 31 & - \\
\hline Individuals & 10739 & 3869 & 6045 & 3645 & 3594 & 1952 & 3094 & 32938 & 997.9 \\
\hline
\end{tabular}

* other mites excluded 
caught have been identified to the species level. The identified material consists of about 400 species.

The largest number of individuals was caught in Ruissalo (2 150 ind./trap/summer) and the smallest in Muntti (620 ind./trap). If Ruissalo (2 150 ind./trap) and Nyynäinen (1 210 ind./trap) with one peak-dominant species are excluded, the total catch varied little (620-775 ind./trap).

The most abundant groups caught were ants (especially in Ruissalo: great dominance of Formica polyctena Förster), oribatid mites, thrips, midges, springtails and leafhoppers (especially in Nyynäinen: great dominance of Alnetoidia alneti (Dahlbom)). Also beetles, spiders, psocopterans and heteropteran bugs were trapped abundantly. Of the abundant groups, the least intersite variation (Table 2) was found for spiders, heteropterans, psocopterans and various hymenopterans (mainly parasitoids). As seen in Table 2, also flying insects were trapped in great numbers.

The most abundant species, as well as some rare (including threatened) species, of certain arthropod groups are presented below. In a separate report (Rinne et al. 1997), a more detailed presentation of the material will be given and (often great) differences between the present data and the data from small window traps on large oaks will be discussed. About 120 species are listed below, including the most abundant species, those associated with oak in Finland and some faunistically interested rarities.

\subsection{Myriapods (Diplopoda, Chilopoda)}

Four species of millipedes (Diplopoda) were caught by branch traps. The southwestern species Nemasoma varicorne C. L. Koch (80 inds.) clearly dominated. It was trapped at all sites except Kurasmäki, as was Proteroiulus fuscus (Am Stein) (17). Both are known as trunk-dwellers, living especially under bark. Other millipedes were the minute Polyxenus lagurus (Linnaeus) in Ruissalo, Kurasmäki and Muntti, and one specimen of the rare Cylindroiulus britannicus (Verhoeff) trapped in Ruissalo. C. britannicus has been regarded as synanthropic in Finland (Lehtinen 1962) but as a trunk-dweller in Great Britain (Blower 1985). Five centipede (Chilopoda) species were found; Lithobius erythrocephalus C. L. Koch, in Ruissalo, and
L. tenebrosus Meinert, in Ruissalo and Muntti, were the most abundant species.

\subsection{Arachnids (Araneae, Opiliones, Pseudo- scorpionida, Acari: Oribatida)}

Altogether, 53 species of spiders (Araneae) were caught by branch traps. The most abundant spiders, all known from tree trunks, were Moebelia penicillata (Westring) (171 inds.), Theridion tinctum (Walckenaer) (155), Anyphaena accentuata (Walckenaer) (82), Drapetisca socialis (Sundevall) (82), Salticus cingulatus (Panzer) (52), $Z y$ giella stroemi (Thorell) (41), Hypomma cornutum (Blackwall) (39) and Steatoda bipunctata (Linnaeus) (37). Five of the eight most abundant species were caught by branch traps at all study sites; Drapetisca socialis, Zygiella stroemi and Steatoda bipunctata at six of the seven sites. In addition to the above-mentioned species, trunk-dwellers include (see Koponen 1996) Micaria subopaca Westring and Nuctenea umbratica (Clerck). The following species are rare in Finland; many of them are restricted to the oak forest zone: Xysticus lanio C. L. Koch found in Ruissalo and Linnavuori, Cheiracanthium oncognatum Thorell in Linnavuori, Clubiona comta C. L. Koch in Ruissalo and Linnavuori, Zygiella atrica (C. L. Koch) in Ruissalo, Theridion pallens Blackwall in Ruissalo and Lenholm, T. tinctum, Agyneta innotabilis (O.P.-Cambridge) in Nyynäinen, Tammimäki and Kurasmäki, Lepthyphantes minutus (Blackwall) in Kurasmäki, and Hypomma cornutum, which seems to be an oak species in Finland. Some species regarded as ground-dwellers were caught on oak branches 3-6 $\mathrm{m}$ above the ground; these include Hahnia pusilla C. L. Koch and Savignya frontata (Blackwall).

Six species of harvestmen (Opiliones) were caught. Rilaena triangularis (Herbst), Mitopus morio (Fabricius) and Leiobunum rupestre (Herbst) were the most abundant species. Nelima gothica Lohmander is a southwestern species; it was found in Ruissalo. The only pseudoscorpion (Pseudoscorpionida) species caught by branch traps was Chernes cimicoides (Fabricius), found in Ruissalo, Tammimäki and Linnavuori.

Oribatid mite (Acari) material included 33 species. Many of the species found are known to be 
arboreous (Ritva Niemi, pers. comm.). The most abundant oribatids were Phauloppia lucorum (C. L. Koch) (1 470 inds.), Eueremaeus oblongus C. L. Koch (1136), Phthiracarus sp. (747), Carabodes labyrinthicus (Michael) (381), Scheloribates latipes (C. L. Koch) (358), Camisia horrida (Herrmann) (157), Zygoribatula exilis (Nicolet) (120), Cymbaeremaeus cymba (Nicolet) (91) and Phauloppia coineaui Trave (72). P. lucorum was the most abundantly trapped oribatid species at four, and Eueremaeus oblongus at two of the seven study sites. The largest number of species and individual numbers were observed in Lenholm and Tammimäki, respectively.

\subsection{Insects (Insecta)}

Psocoptera

A great proportion (40\%) of the Finnish psocopterans was trapped: 25 species. The most abundant species were Loensia pearmani Kimmins (183 inds., perhaps some females of $L$. variegata (Latreille), are included), Pseudopsocus fusciceps (Reuter) (166), Loensia fasciata (Fabricius) (140), Graphopsocus cruciatus (Linnaeus) (64), Trichadenotecnum majus (Kolbe) (60) and Reuterella helvimacula (Enderlein) (41). Loensia pearmani and Trichadenotecnum majus were caught at all seven study sites, and Loensia fasciata, Graphopsocus cruciatus and Reuterella helvimacula at six sites. Rare species (see Kanervo \& Rinne 1996) included the above-mentioned Pseudopsocus fusciceps found at all sites except "inland woodlands" Tammimäki and Kurasmäki, Lachesilla quercus (Kolbe) in Ruissalo and Lenholm, Loensia variegata $\left(\sigma^{7}\right)$, earlier known only from Åland in Finland, found in Lenholm, and Trichadenotecnun incognitum Roesler, trapped in Tammimäki and previously known only from the Pyhä-Häkki National Park, Central Finland.

\section{Neuroptera and Blattodea}

The minute neuropteran, Coniopteryx borealis Tjeder is an oak species; it was found at most sites. Six neuropteran species were caught by branch traps. Ectobius sylvestris (Poda) was the only cockroach species.

\section{Homoptera}

Of the psyllids, Trioza remota Förster is an oak species. It was trapped in Tammimäki and Muntti. Four aphid species are known to live on oak in continental Finland (one additional in the Åland islands; A. Albrecht, pers. comm.); all four were caught by branch traps. The most abundant species was Thelaxeres dryophila (Schrank) (39 inds.) trapped in Ruissalo and Tammimäki. Tuberculatus annulatus (Hartig) (14) was found at all sites. Lachnus roboris (Linnaeus) (24) is associated with ants; it was found at sites with high ant abundance, i.e. Ruissalo, Tammimäki and Linnavuori. Phylloxera coccinea von Heyden was trapped only in Tammimäki. Great numbers of flying aphids only occasionally found on oaks were collected.

Thirteen species of leafhoppers were caught. The dominant species, Alnetoidia alneti, living especially on Tilia, was extremely abundant in Nyynäinen (2 913 inds.) but also found in Ruissalo, Linnavuori and Tammimäki. Interestingly, despite being a good flier, $A$. alni was found in much smaller numbers in window traps than in branch traps in Nyynäinen. Oak species included Iassus lanio (Linnaeus) caught in Ruissalo and Kurasmäki, Eurhadina concinna (Germar) in Lenholm, and E. pulchella (Fallén) in Tammimäki, Kurasmäki and Muntti; all these species were trapped in low numbers. Of these, E. concinna is a rare species, as well as Edwardsiana frustrator (Edwards), which was found in Linnavuori.

\section{Heteroptera}

Altogether 31 heteropteran bugs were trapped on branches. The most abundant species, found at all sites, were Calocoris ochromelas (Gmelin) (331 inds.), a typical oak species, and two trunkand branch-dwelling predators Loricula pselaphiformis Curtis (250) and Temnostethus gracilis (Horvath) (75). Interesting trunk/branch species were also Empicoris vagabundus (Linnaeus), found in Tammimäki and Muntti, and Myrmedobia distinguenda Reuter found in good numbers (41) in Lenholm, Tammimäki and Muntti; the last mentioned is known from lichen-covered branches of conifers. Oak species were, in addition to Calocoris ochromelas, Pilophorus perplexus (Doug- 
las \& Scott) found in Ruissalo, Cyllecoris histrionicus (Linnaeus) in Ruissalo, Lenholm, Tammimäki and Linnavuori, Dryophilocoris flavoquadrimaculatus (De Geer) in Nyynäinen, Phylus melanocephalus (Linnaeus) in Ruissalo, Lenholm, Tammimäki and Kurasmäki, Psallus mollis (Mulsant \& Rey) trapped at all sites except Tammimäki and Kurasmäki, $P$. perrisi (Mulsant \& Rey) and $P$. variablis (Fallén), which were found at most sites, and the most rare species, $P$. wagneri Ossiannilsson trapped in Ruissalo.

\section{Coleoptera}

The most abundant beetles, among the 148 trapped species, were Dorcatoma chrysomelina Sturm (234 inds.), found at six sites, Dromius agilis (Fabricius) (81) at all seven sites, Amischa nigrofusca (Stephens) (81) all sites, Hapalarea ioptera (Stephens) (70) all sites, Leptusa ruficollis (Erichson) (57) only in Ruissalo, Enicmus rugosus (Herbst) (49) at six sites, Amischa decipiens (Sharp) (48) all sites and Ptinus subpilosus Sturm (46) at all sites. The following seven threatened species (see Rassi et al. 1992) were caught by branch traps: Plectophloeus nitidus (Fairmaire) in Ruissalo and Nyynäinen, Plegaderus caesus (Herbst) in Ruissalo, Paromalus flavicornis (Herbst) in Ruissalo, Ampedus nigroflavus (Goeze) in Nyynäinen, Prionychus ater (Fabricius) in Lenholm and Muntti, Mycetochara humeralis (Fabricius) in Ruissalo, Lenholm and Nyynäinen, and Scraptia fuscula Müller in Ruissalo. According to Karhu et al. (1995), the last finding of Paromalus flavicornis from Ruissalo was made in 1948. Some other rare species were also trapped: Quedius brevicornis Thomson in Ruissalo and Nyynäinen, Pachyatheta mortuorum (Thomson) in Lenholm, Thamiaraea hospita (Märkel) in Lenholm, Euplectus kirbyi Denny in Nyynäinen, Mycetophagus decempunctatus Fabricius in Nyynäinen and Otiorhynchus singularis (Linnaeus) in Ruissalo. Typical oak species included Dromius quadrimaculatus (Linnaeus) trapped at all sites except Nyynäinen, Xyletinus pectinatus (Fabricius) in Ruissalo and Kurasmäki, Coeliodes dryados (Gmelin) in Kurasmäki and Scolytus intricatus (Ratzeburg) in Linnavuori and Muntti. In addition to the four listed oak species, the following six above-mentioned beetles are also associated with oaks in Finland: Dorcatoma chrysomelina, Leptusa ruficollis, Plectophloeus nitidus, Plegaderus caesus, Paromalus flavicornis, and Thamiaraea hospita.

\section{Lepidoptera}

The most abundant microlepidopterans among the 43 species found were two oak species, Zeiraphera isertana (Fabricius) (400 inds.), found at all sites, and Psoricoptera gibbosella (Zeller) (55) at all sites except Muntti. The following oak species were trapped rather abundantly: Pammene argyrana (Hübner) in Ruissalo, Lenholm, Nyynäinen, Kurasmäki and Muntti, Eriocrania subpurpurella (Haworth) in Tammimäki, Kurasmäki and Muntti, Ypsolopha ustella (Clerck) in Ruissalo, Lenholm, Tammimäki and Muntti, and Y. sylvella (Linnaeus) in Lenholm, Tammimäki, Kurasmäki, Linnavuori and Muntti. Many typical oak species were caught only in low numbers by branch traps, such as Tortrix viridana (Linnaeus), Tischeria ekebladella (Bjerkander), Acleris ferrugana (Denis \& Schiffermüller) and Stenolechia gemmella (Linnaeus). Rare microlepidopterans included Klimeschiopsis kiningerella (Duponchel) in Nyynäinen and the oak species Pammene splendidulana (Guenée) in Kurasmäki.

Of the 18 macrolepidopteran species trapped, Amphipyra specimens were found commonly. They are known to run rapidly, probably also on branches. Amphipyra berbera Rungs was the most abundant macrolepidopteran species found in Ruissalo, Lenholm, Nyynäinen, Tammimäki and Linnavuori; the expansion species A. perflua $(\mathrm{Fa}-$ bricius) was caught in Nyynäinen.

Formicidae (Hym.)

Altogether, 14 ant species were caught by branch traps. The most abundant insect species in traps, Formica polyctena, was very abundant in Ruissalo; it was also numerous in Linnavuori and Tammimäki. Myrmica ruginodis Nylander was also common and caught at most sites. Other frequently trapped species were Formica rufa Linnaeus, $F$. fusca Linnaeus and Lasius niger (Linnaeus). A little collected species, L. mixtus (Nylander), 
was trapped in Ruissalo, Tammimäki and Kurasmäki.

\section{Conclusions}

The number of typical oak-dwellers or rare southwestem species was highest in Ruissalo, the largest oak woodland in Finland. At other sites, the area of the oak forests studied ( $0.5-8$ ha) had no marked effect on the total number of typical species and even in the smallest isolated forest the typical oak fauna was found. The highest species number for many groups was also found in Ruissalo, e.g. for Myriapoda, Araneae, Psocoptera and Heteroptera, but not for Oribatida and Coleoptera, where the highest diversity was observed in Lenholm and Nyynäinen, respectively.

The new trap is suitable for collecting groups moving on branches, although also flying insects were caught. For example, the psocopteran $P$ seudopsocus fusciceps, which has been found earlier very seldomly, was now caught in good numbers by the present traps (cf. Kanervo \& Rinne 1996). The same was true for certain spiders (Hypomma cornutum), heteropterans (Myrmedobia distinguenda) and beetles (Plectophloeus nitidus and Leptusa ruficollis). The combined use of the present trap and other trap types (e.g. window traps) is recommended when studying the total arthropod fauna of oak canopy (see Rinne et al. 1997).

Acknowledgements. This study was supported by the Archipelago Park Area of the Finnish Forest and Park Service. The following persons kindly determined material or helped in identification: Anders Albrecht (Aphidoidea), Jussi Kanervo (Psocoptera), Tapio Lammes (Neuroptera, Psyllodea), Pekka T. Lehtinen (Diplopoda, Chilopoda, Pseudoscorpionida), Ritva Niemi (Oribatida), Tomi Saarinen (Lepidoptera) and Michael Saaristo (Formicidae). Ari Karhilahti helped in planning the branch trap and David Bergen checked the English. Juha Siitonen made valuable comments on the manuscript. We thank them all.

\section{References}

Blower, J. G. 1985: Millipedes. - Synopses of the British Fauna (New Ser.) 35: 1-242.

Kanervo, J. \& Rinne, V. 1996: Psocopteran fauna of oak forests in SW Finland - Sahlbergia 3: 21-23. (In Finnish, with English summary.)

Karhu, K., Rassi, P. \& Rutanen, I. 1995: Threatened insects of Ruissalo. - Entomol. Fennica 6: 123-125.

Koponen, S. 1996: Spiders (Araneae) on trunks and large branches of oak (Quercus robur) in SW Finland. Rev. Suisse Zool. vol. hors ser.: 335-340.

Koponen, S., Niemelä, P., Lindgren, M. \& Karhu, K. 1990: (On damage by tortricids in oak forests in Ruissalo.) Turun ympäristönsuojelutoimiston julk. 6/90: 1-48. (In Finnish.)

Laamanen, M. 1938: Übersicht der Käferfauna der Eichenbestände von Ruissalo bei Turku. - Ann. Univ. Turkuensis Ser. A 6(7): 1-52. (In Finnish, with German summary.)

Lahtiperä, E. K. 1955: (Specialities of beetle fauna in Ruissalo.) - Turun Ylioppilas 4: 219-228. (In Finnish.)

Lehtinen, P. T. 1962: The symphylid, diplopod, and chilopod fauna of SW-Häme. - Lounais-Hämeen Luonto 13: 32-37. (In Finnish, with English summary).

Nicolai, V. 1986: The bark of trees: thermal properties, microclimate and fauna. - Oecologia 69: 148-160.

Rassi, P., Kaipainen, H., Mannerkoski, I. \& Ståhls, G. 1992: (Report on the monitoring of threatened animals and plants in Finland.) - Committee report 1991: 30. Ministry of the Environment. Helsinki. 328 pp. (In Finnish.)

Rinne, V., Clayhills, T. \& Koponen, S. 1997: On invertebrates of protected oak groves in southwestern Finland. - Metsähallituksen luonnonsuojelujulk. A. (In Finnish, with English summary.) (In press.)

Ruzicka, V. \& Bohac, J. 1991: Invertebrate animals from hollow trees in the Trebon basin. - Sbor. Jihoces. Muz. v. Ces. Budejovivich Prir. Vedy 31: 33-46. (In Czech, with English summary.)

Salmikivi, H. 1931: (On morphology and bionomics of oakdwelling lepidopteran larvae in Ruissalo.) - Unpubl. thesis, Dept. Biology, Univ. Turku. 152 pp. (In Finnish.)

Simon, U. 1995: Untersuchung der Stratozönosen von Spinnen und Weberknechten (Arachn.: Araneae, Opilionida) an der Waldkiefer (Pinus sylvestris L.). - Wissenschaft und Technik Verlag Gross, Berlin. xiv + 142 pp. 


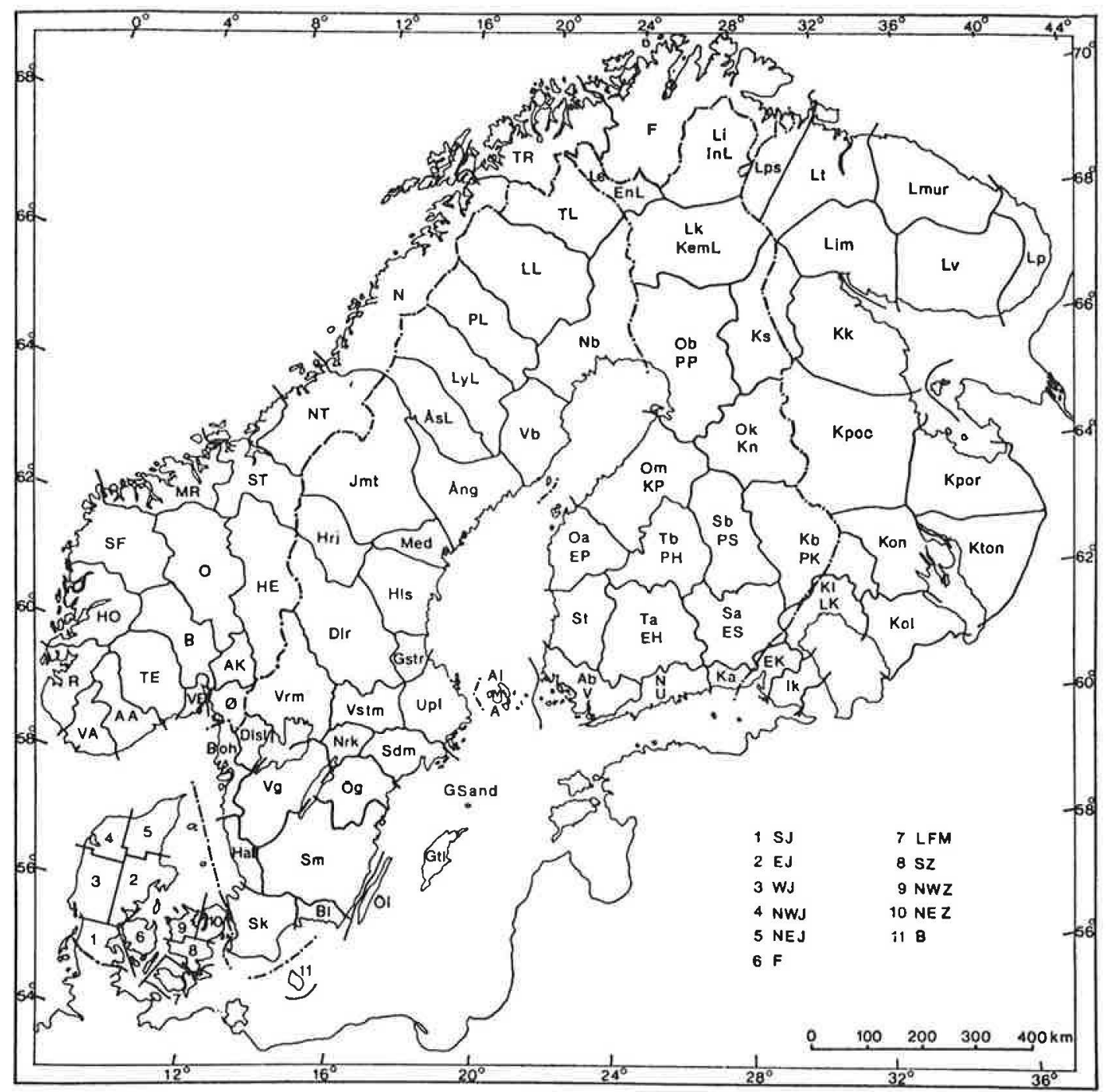

The biogeographical provinces of Fennoscandia and Denmark 